\title{
A despatriarcalização de Deus na teologia feminista
}

\author{
Jaci de Fátima Souza Candiotto' ${ }^{1}$ (iD 0000-0002-1780-545X \\ 'Pontifícia Universidade Católica do Paraná, Curitiba, PR, Brasil. 80215-901 - \\ ppgdh@pucpr.br
}

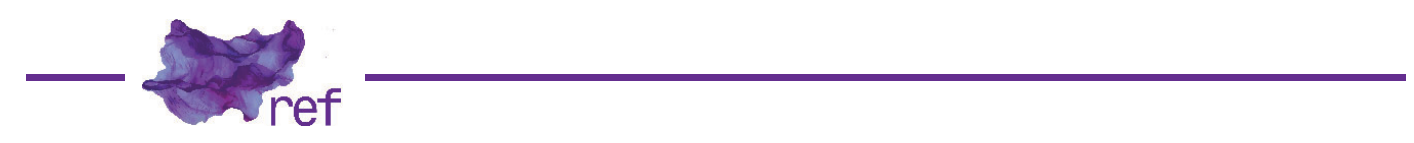

Resumo: Neste artigo, analisamos a importância da linguagem para a compreensão do divino e de nós mesmas/os pelo exame das nomeações clássicas que foram identificadas com figuras historicamente patriarcais. Ao fazer este percurso, evocando a estratégica da hermenêutica bíblica feminista, objetivamos desconstruir estas identificações e ressituá-las metaforicamente; privilegiar nomeações que se afastam da normatividade masculina para se referir a Deus. Geralmente, estas imagens estão associadas a um poder patriarcal, onde predomina uma linguagem metafísica e objetiva. Não obstante, quando essas imagens estão associadas a relações de reciprocidade, de inclusão das diferenças e do respeito da pluralidade, a linguagem é predominantemente metafórica. Além de estabelecer o contraste entre essas duas formas de linguagem, nossa hipótese é de que esta última é a mais adequada para se referir a Deus na época atual.

Palavras-chave: patriarcado; teologia feminista; nomeação divina; linguagem metafórica.

God's Depatriarcalization in Feminist Theology

Abstract: In this paper we analyze the importance of language for the understanding of the divine and of ourselves and we examine classic appointments that have been identified with historically patriarchal figures. In making this journey from the feminist biblical hermeneutics strategy, we aim to deconstruct these identifications and to resituate them metaphorically, privilege appointments that deviate from masculine normativity to refer to God. Generally when these images are associated with a patriarchal power, a metaphysical and objective language predominates. Nevertheless, when these images are associated with relations of reciprocity, inclusion of differences and respect of plurality, language is predominantly metaphorical. In addition to establishing the contrast between these two forms of language, our hypothesis is that the latter is the most adequate to refer to God in the present time.

Keywords: Patriarchate; Feminist theology; Divine appointment; Metaphorical language.

\section{La despatriarcalización de Dios en la teología feminista}

Resumen:En este artículo analizamos la importancia del lenguaje para entender a Dios y a nosotros/as mismos/as examinando las nominaciones clásicas que se han identificado con figuras históricamente patriarcales. Al hacer este camino, evocando la estrategia de la hermenéutica feminista bíblica, nuestro objetivo es deconstruir estas identificaciones y reemplazarlas metafóricamente; privilegiar las nominaciones que se desvían de la normatividad masculina para referirse a Dios. Habitualmente estas imágenes se asocian a un poder patriarcal, en el cual predomina un lenguaje metafísico y objetivo. Sin embargo, cuando estas imágenes se asocian a relaciones de reciprocidad, inclusión de diferencias y respeto por la pluralidad, el lenguaje es predominantemente metafórico. Además de establecer el contraste entre estas dos formas de lenguaje, nuestra hipótesis es que esta última es la más adecuada para referirse a Dios en la época actual.

Palabras clave: patriarcado; teología feminista; nombramiento divino; lenguaje metafórico.

\section{Introdução}

A linguagem sobre Deus/a não pode validar os papéis de homens ou mulheres de formas estereotipadas que justifiquem a dominação masculina e a subordinação feminina (Rosemary Radford RUETHER, 1993, p. 63) 
A principal dificuldade da hermenêutica bíblica feminista é a constatação de que a linguagem patriarcal dos textos sagrados foi naturalizada e cristalizada como parte do conteúdo revelado. Já sua riqueza é ter demonstrado que a linguagem não é o conteúdo, que o significado da mensagem pode ser extraído distintamente de seu veículo de transmissão.

A hermenêutica bíblica feminista vem justamente desconstruir a mentalidade patriarcal que se esconde por detrás da linguagem que transmite o conteúdo revelado. Ela propõe que os contextos do passado devem ser ressignificados, e as identidades que eles instituem renomeadas. Não se pode ler a Bíblia somente em função da reprodução do contexto do passado no presente. É necessário ler o passado a partir de nosso contexto, de nossas experiências, para que a Palavra tenha um novo significado.

O imaginário que cerca a nomeação de Deus quase sempre esteve preso no passado, condicionando nosso presente e nosso futuro. Depreende-se a tarefa de propiciar outro sentido para as nomeações já existentes, relativizando perspectivas discriminatórias e hierárquicas e empreendendo o caminho incessante, mas sempre insuficiente, de renomear o divino a partir de nossa realidade.

Portanto, é desejável que o passado seja lido da perspectiva do presente e do futuro e, consequentemente, que o real seja interpretado a partir do possível. Em seguida, convém reconhecer que a linguagem, mais do que tentar se adequar a um real já dado, muitas vezes configura e constitui a realidade.

Hoje, sobretudo a partir dos estudos da física quântica e da neurociência, aprendemos que necessário se faz recuperar a prioridade do futuro sobre o passado na concepção do tempo e a prioridade da potencialidade sobre o real no conceito de realidade. Pois, na verdade, é o futuro que acorda as potencialidades adormecidas do passado e não o contrário. Da mesma forma, cada realidade se revela apenas como uma entre tantas possíveis realizações, embora essa concretização seja irreversível. Só assim poderemos compreender, de fato, o devir como o princípio que estrutura a inteira realidade, tornando-a um autêntico sistema aberto, vale dizer, num contínuo processo incompleto porque em vias de completude (Sinivaldo TAVARES, 2010, p. 88).

O significado das nomeações do Deus revelador não pode permanecer fixo no passado. A Revelação apresenta-se antes como um processo revelador extensivo ao presente e ao futuro. Na esteira de J. Moltmann, a proposta de Tavares (2010, p. 88) é pensar o Deus bíblico como "possibilitação máxima do possível" e não como "determinação de todo real".

Quanto a reconhecer a importância da linguagem na atribuição de realidade, trata-se de empreitada imprescindível se quisermos ressignificar contextos e renomear identidades. Lembra Georges Gusdorf (1990, p. 11) que, no mundo humano, "a palavra tem maior importância que a coisa"; o mundo é "um universo de designações e de ideias". A linguagem configura nosso mundo e organiza nossa realidade. Embora a palavra não crie a coisa, ela institui sentido, dá consistência à realidade; ela é, ao mesmo tempo, espaço de poder e de realização. É esse poder da linguagem para dar consistência à realidade que nos convida a atribuir novos nomes para Deus, assim como estabelecer uma análise crítica dos preconceitos culturais que envolveram outras nomeações divinas e tolheram às mulheres a expressão de sua relação com Deus desde sua especificidade, mas também a partir de sua universalidade, na condição de seres humanos.

Com efeito, as mulheres estão numa relação paradoxal com a linguagem e com o seu uso, na medida em que o logos da linguagem - ou melhor, a linguagem como logos - tal como a tradição ocidental o foi estruturando, é autarquicamente masculino, não simbolizando o masculino e o feminino no mesmo plano nem com o mesmo valor semântico (Fernanda HENRIQUES, 2003, p. 4).

Em vistas de se contrapor a essa hierarquia do logos ocidental que permeia nossa linguagem religiosa, diversos trabalhos hermenêuticos de teólogas feministas têm mostrado a insuficiência das nomeações androcêntricas referentes a Deus. Ele, Pai, Senhor, Rei, Juiz, Esposo e atributos como Todo-Poderoso, Glorioso e Onisciente vieram revelar até que ponto "as produções teológicas seguem as produções culturais, mesmo quando expressam posturas de 'contra-corrente'" (Ivone GEBARA, 2000, p. 276).

As relações entre mulheres e homens operam nas elaborações dos significados religiosos em nossa vida, inclusive nas nomeações históricas de Deus. Rei e Senhor, por exemplo, têm denotado a imagem de um Deus distante, em relação de verticalização com seus súditos e servos dos quais são exigidas obediência e fidelidade. Essas nomeações têm sido enfatizadas principalmente em culturas políticas marcadas pelo despotismo político e por sistemas econômicos escravocratas e feudais. Pai e Esposo - apesar da simbologia afetiva que lhes parece constitutiva - têm sido usados para caracterizar o governo da casa, dos filhos e da esposa. Por sua vez, Juiz normalmente vem demarcar a imagem de um Deus que condena e que separa entre justos e injustos. 
A apropriação patriarcal dessas nomeações legou à posteridade a imagem de um Deus eminentemente Soberano, hierarquicamente distante da vida cotidiana e extremamente separado do mundo material. Ana Maria Tepedino (textos avulsos, p. 6) reforça as principais consequências da imagem patriarcal de Deus. Ela:

- legitima e reforça as estruturas sociais patriarcais na família, na sociedade e na igreja;

- justifica a visão androcêntrica do mundo em relação à superioridade do homem e à inferioridade da mulher, sacralizando o masculino.

- $\quad$ possibilita ao homem o papel de Deus como seu representante no mundo:

- apresenta a mulher como dependente e pecadora;

- nega à mulher a experiência de ter sua identidade sexual plenamente afirmada à imagem e semelhança de Deus, debilitando seu sentimento de dignidade e autoestima;

- reduzindo o Mistério divino à metáfora do homem dominante (patriarca/kiriarcal), esta imagem de Deus se transforma num ídolo, e se torna artífice de injustiça e fonte de escravidão para as mulheres, os pobres, os negros, os amarelos, os indígenas.

Um dos desafios prementes da teologia atual, particularmente da teologia feminista, é o de procurar falar de Deus, salvaguardando ao mesmo tempo sua transcendência e relação com o mundo, constituído por mulheres, homens e todos os demais seres animados e inanimados (Teresa Martinho TOLDY, 1998, p. 167).

Nessa árdua tarefa de buscar a compreensão da fé, as teólogas feministas de diferentes denominações e culturas têm se concentrado no ponto central de um sistema de crença que é a nomeação da divindade. Entende-se que isto tem consequências críticas, pois ela organiza os outros aspectos do sistema religioso.

\section{Deus como pai}

Uma das principais questões da teologia feminista diz respeito à simbologia da nomeação divina como Pai, já que esse substantivo foi modelado pelo imaginário patriarcal para justificar a condição subalterna das mulheres. Referir-se a Deus como Pai em uma cultura patriarcal significa também afirmar a masculinidade de Deus: a redução do mistério de Deus à sua identificação "com um ELE, um ser masculino" (Maria Clara Lucchetti BINGEMER, 2008, p. 46). Na teologia feminista contemporânea, a imagem de Deus Pai tem sido reinterpretada de maneira crítica. No entender de Mary Daly (1975, p. 16), o cristianismo tratou de reforçar ainda mais essa simbologia em virtude da masculinidade do Filho, Jesus Cristo, encarregado da remissão dos pecados do mundo.

A problemática surge em razão das consequências desta simbologia em termos de estruturas patriarcais. Uma delas é legitimar negativamente a verticalização como paradigma de relações humanas sob as formas do autoritarismo religioso, do despotismo político, da dominação paterna no lar.

Rosino Gibellini (1992, p. 102) sustenta que, para encarar essa problemática, a teologia feminista percorreu um duplo caminho:

Ou se recuperam, ao longo de todo o traçado da Bíblia e da tradição, embora sublinhando que Deus está além das caracterizações e diferenciações sexuais, as imagens femininas que exprimem Deus, para contrabalançar os preponderantes, para não dizer exclusivos, imaginário e linguagem masculinos; ou então se submete à rigorosa análise teórica o conceito de paternidade atribuído a Deus.

Em boa parte da teologia feminista predominou a escolha pelo resgate bíblico de imagens femininas e maternais de Deus em contraste ao imaginário e linguagem masculinos. Phyllis Trible (1973), por exemplo, mostrou que o imaginário feminino referente a Deus no Antigo Testamento é muito frequente. No Êxodo, ele está relacionado a Deus que sacia a fome e a sede dos seus filhos errantes no deserto. Fornecer alimento e água era um trabalho de mulheres no Antigo Testamento (AT) e ele é assumido por Yahweh. Assim como as mulheres buscam água para suas famílias, também Yahweh encontra água para seus filhos no deserto (BíBLIA DE JERUSALÉM, 2004, Ex 17, 1-7); da mesma maneira que as mulheres alimentam seu lar, Yahweh igualmente provê o povo com maná e codornas (BÍBLIA DE JERUSALÉM, 2004, Ex 16, 4-36). Além disso, outras imagens como parteira (BÍBLIA DE JERUSALÉM, 2004, Sal 21, 9-10), costureira (BíBLIA DE JERUSALÉM, 2004, Nee 9, 21); enfermeira (BÍBLIA DE JERUSALÉM, 2004, Is 49, 15), governanta do lar que veste seus filhos (BíBLIA DE JERUSALÉM, 2004, Prov 31, 21 f) e mãe (BíBLIA DE JERUSALÉM, 2004, Is 49,15 ) estão presentes no AT. No entanto, a figura sobressalente utilizada pela hermenêutica teológica feminista tem sido a de Sabedoria (sophia, em grego; sapientia, em latim). Também na América Latina, principalmente no momento já conhecido como teologia feminista, insistiu-se frequentemente em mostrar as características femininas do Deus bíblico. Sobre isso, Elsa Tamez (1998) pondera que não é suficiente trabalhar 'o rosto feminino de Deus' visto que, ao insistir nisso, resultou, por um lado, em relevar valores muitas vezes impostos como femininos; e igualmente 
se reconhece que se está no interior dos parâmetros de um discurso teológico patriarcal, ainda que feminizado. Considera-se, portanto, que tal produção desandou uma produção teológica feminista patriarcal. Para a autora, cabe às teólogas reconstruir toda a teologia e os textos bíblicos com categorias inclusivas e menos ocidentais (TAMEZ, 1998, p. 57-58).

Não insistiremos nessas atribuições, visto que já foram muito trabalhadas em décadas anteriores, sendo mais objeto de uma prospectiva do que propriamente de uma perspectiva teológica feminista. A ponderação de Trible a esse respeito parece oportuna:

Embora o Antigo Testamento frequentemente apresente Yahweh como um homem, ele também usa a linguagem ginomórfica para a divindade. Da mesma maneira, Israel repudiou a ideia de sexualidade em Deus. Ao contrário das deusas da fertilidade, Yahweh é nem macho nem fêmea; nem ele ou ela. Em consequência, as afirmações modernas de que Deus é masculino, até mesmo quando elas são qualificadas, são enganosas e prejudiciais, se não totalmente imprecisas. As limitações culturais e gramaticais (o uso do pronome masculino para Deus) não podem limitar a compreensão teológica. Como Criador e Senhor, Yahweh envolve e transcende ambos os sexos. Traduzindo para nossa preocupação imediata: a natureza do Deus de Israel se opõe ao sexismo (TRIBLE, 1973, p. 34, tradução nossa).

Gibellini salienta que quando expoentes da teologia feminista optam pela recuperação da feminilidade de Deus não almejam afirmar um deus andrógino, limitado a uma realidade mundana de ordem sexual. Muito pelo contrário. Conscientes da transcendência divina em relação ao mundo, autoras como Phyllis Trible, Elisabeth Schussler Fiorenza, Rosemary R. Ruether - acrescentaríamos Maria Clara Bingemer e Ana Tepedino - buscam "corrigir e integrar a linguagem religiosa sexista numa linguagem mais integral e universal, menos inadequada a exprimir a Transcendência" (GIBELLINI, 1992, p. 103).

Como a cultura religiosa está permeada de uma linguagem de sustentação eminentemente patriarcal, a teologia feminista insiste na proposição de "uma linguagem inclusiva para Deus que recorra às imagens e experiências de ambos os sexos" (RUETHER, 1993, p. 61). O equilíbrio das relações humanas está no reconhecimento verbal e não verbal de sua dignidade. Ainda que o apelo à feminilidade de Deus tenha sido um passo importante da teologia feminista, mesmo que a atribuição de uma linguagem ginomórfica integradora seja igualmente relevante, mais significativa, no nosso entender, é a ideia de despatriarcalizar Deus como Pai.

Paul Ricoeur (1969), em seu texto "La paternité - du fantasme au simbole" (1969), ' salientou a escassez significativa no Antigo Testamento da nomeação de Deus como Pai. Mais frequente é a imagem de Deus como herói de uma narrativa da libertação, de onde a insuficiência da figura parental como metáfora para Deus.

Assim, a evolução da figura do pai rumo a um simbolismo superior é tributária de outros símbolos que não pertencem à esfera de parentesco; o libertador da "saga" hebraica primitiva, o doador da lei do Sinai, o portador do Nome sem imagem e até o criador do mito da criação: outras tantas designações fora do parentesco... (RICOEUR, 1969, p. 476, tradução nossa).

Ricoeur lembra ainda que o tema da Aliança, fundamental no Antigo Testamento, não envolve de maneira prioritária uma relação de parentesco. Já no Novo Testamento, ainda que Jesus personifique a imagem do Filho, a chave de análise dos Evangelhos é o Reino² a partir do qual a paternidade precisa ser situada. Essas observações do autor nos ajudam a dissociar a figura do pai dos preconceitos do patriarcado, assim como a propor uma redefinição geral da família.

Poder-se-ia dizer que tanto na linguagem do AT quanto na do Novo Testamento (NT) há a ideia de que a obediência a Deus e o seguimento de Jesus, respectivamente, implicam redefinir a importância da família de um modo geral, e ressignificar a nomeação divina como Pai de modo particular. Comecemos pela redefinição da família. Na família judaica da época de Jesus, as mulheres são propriedades dos maridos, com escassez de direitos e acúmulo de deveres, muitos deles voltados para a realização das atividades do lar.

Devia moer, cozinhar, lavar, amamentar os filhos, fazer a cama do marido e, para compensar sua manutenção, fiar e tecer lã [...]; a mulher era obrigada a obedecer ao seu marido como seu senhor [...]. As relações entre filhos e pais eram também determinadas pela obediência que

\footnotetext{
1 Esse texto não pode ser considerado uma análise feminista. O objetivo de Ricoeur é questionar a suficiência da imagem de Deus-Pai como fantasma, como modelo puramente regressivo e infantilizador no pensamento de Freud. No entanto, esse objetivo indiretamente levou-o a pôr em crise a legitimidade da exclusividade da metáfora parental para a nomeação de Deus e se constitui, portanto, como uma tentativa válida de renomeação de Deus. Ele irá mostrar que, no Antigo Testamento, a palavra Pai, para se referir a Deus, aparece somente 20 vezes e, concentradamente, nos escritos proféticos. Se a profecia está direcionada para o futuro e não necessariamente para uma situação passada ou sedimentada no presente, então é porque essa metáfora não invoca uma nostalgia em relação ao passado.

2 No sentido de Reino de Amor e de Justiça, tal como inaugurado por Jesus de Nazaré, e não como a imagem monárquica de um Deus que Reina soberanamente, distante do mundo e de seus problemas.
} 
a mulher devia a seu marido; os filhos tinham que colocar o respeito ao pai acima do respeito à mãe (Joachim JEREMIAS, 1983, p. 485).

Nos costumes judaicos, as mulheres deveriam romper com seus pais para viver com a família do marido, a fim de dar continuidade sociológica à família patriarcal ou clã. A família patriarcal preservava o poder dos homens sobre as mulheres. O próprio termo hebraico bêtab (casa do pai) designa a superioridade masculina (John L. MACKENZIE, 1983, p. 337). Na representação patriarcal, a finalidade exclusiva da família era a procriação. Esta sequência da linhagem sanguínea garantia a sobrevivência de Israel, herdeiro da promessa do Messias. Por essa razão, todo nascimento, sobretudo se a criança fosse do sexo masculino, era tido como uma bênção. "É característica a alegria ao nascer um menino, enquanto o nascimento de uma menina é acompanhado de indiferença, até mesmo de tristeza" (JEREMIAS, 1983, p. 493).

Nessa perspectiva é que se torna possível entender melhor o choro das mulheres estéreis no Antigo Testamento. Não ter filhos, voluntariamente ou não, era visto como uma maldição de Deus no AT; também morrer na cruz ou no madeiro era algo próprio dos malditos. Se a procriação era uma maneira de projetar a eternidade no imaginário do pai de família, a morte e ressurreição de Jesus redefinem a concepção de eternidade, dissociando-a da necessidade da procriação. Desde a Anunciação em Nazaré, quando o Anjo comunica Maria que ela seria Mãe do Filho de Deus, até o Calvário, os Evangelhos são unânimes em mostrar que Jesus prioriza como família aqueles e aquelas que se reúnem em torno dele e de sua mensagem.

Jesus é concebido segundo o Espírito (BÍBLIA DE JERUSALÉM, 2004, Lc 1); por ocasião de sua apresentação no Templo, aos doze anos, ele se perde de sua família. Ao encontrá-lo depois de dois dias de procura, Jesus torna irrelevante a preocupação de Maria ao afirmar ter estado preocupado com "as coisas do Pai" (BÍBLIA DE JERUSALÉM, 2004, LC 2, 49); quando alguém no meio do povo afirma: "Felizes as entranhas que te trouxeram e os seios que te amamentaram!" (BÍBLIA DE JERUSALÉM, 2004, LC 11, 27), Jesus responde: "Felizes antes os que ouvem a palavra de Deus e a observam!" (BÍBLIA DE JERUSALÉM, 2004, LC 11, 28); "Minha mãe e meus irmãos são aqueles que ouvem a palavra de Deus e a põem em prática" (BÍBLIA DE JERUSALÉM, 2004, LC 8, 21); e, no final de sua vida terrena, aos pés da cruz, entrega Maria como mãe a João. 0 conjunto dessas ações, palavras e atitudes denota a insistência de Jesus sobre a relativização da família segundo as determinações da época.

Analisadas sob a perspectiva da hermenêutica teológica feminista, tais passagens são reflexos da novidade trazida por Jesus. Ao propor para a sociedade patriarcal um Reino diferente - o Reino de Deus -, isso significa propor a valorização de novas relações humanas. A felicidade consiste primeiramente na escuta da palavra de Deus e sua observância (BíBLIA DE JERUSALÉM, 2004 , cf. LC 11, 27s). Diferentemente da concepção da família patriarcal antiga, o "discipulado fiel e não a maternidade biológica é a vocação da mulher" (Elisabeth SCHÜSSLER FIORENZA, 1992, p. 182). Significativo é constatar que os membros constitutivos dessa nova família nos evangelhos são os irmãos, irmãs, mães, na maioria das vezes fazendo omissão da presença do pai.

Quando surgiu na Palestina, o movimento de Jesus adotava uma ética antifamilial, recomendando aos discípulos de Jesus que rompessem todos os laços com a família patriarcal e deixassem o lar (e a autoridade que ali exerciam ou sobre eles se exercia), irmãos, irmãs, mãe, pai, pelo Reino de Deus. No 'discipulado de iguais' haverá outra vez irmãos e irmãs, mães e filhos, mas nenhum pai. O patriarcado e seu papel central estão superados. Deveria essa ética ser posta em prática não só pelos missionários itinerantes, mas também por aqueles discípulos que ficassem em casa. Nada se fala, nas tradições mais antigas, quanto a abandonar mulher ou marido, mas se o patriarcado ficar abolido, então os papéis de mulher-e-marido se tornam papéis de serviço recíproco, e ocorre até uma inversão de papéis. Os 'últimos' tornam-se agora os 'primeiros' (cf. Mc 10, 29-31 par., e também Mc 3, 31-35; Lc 11, 27-28; Mc 10, 42-45; MT 23, 8, 11 entre outros) (Linda M. MALONEY, 1991, p. 59).

Além do exposto acima, há de se notar que as mulheres são amplamente incluídas entre os discípulos de Jesus.

O contexto narrativo torna claro que os que 'fazem a vontade de Deus' reúnem-se em discipulado para formarem uma nova 'família'. Jesus está 'dentro' de casa, em 'casa' (cf. 3, 19). Jesus aponta 'aos que estavam assentados a seu redor' e declara que eles são sua verdadeira 'família' (v. 34). A comunidade do discipulado abole as pretensões da família patriarcal e constitui uma nova comunidade familiar, uma comunidade que não inclui os pais em seu círculo (SCHÜSSLER FIORENZA, 1992, p. 183).

No evangelho de Marcos, a proposta de Jesus é correlata da ruptura da família patriarcal. Importa a adesão a Jesus e a sua proposta. Essa nova família é a comunidade messiânica. Ela é uma nova fraternidade ou sororidade (Marcela LAGARDE Y DE LOS RíOS, 2012, p. 543), constituída pelos empobrecidos/as e marginalizados/as. Mulheres e homens a ela são chamados para formar um "novo parentesco e família baseados no discipulado radical" (SCHÜSSLER FIORENZA, 1992, p. 183). Há uma mudança nas estruturas patriarcais. Os que ocupavam o lugar mais baixo 
são apontados como modelos do autêntico discipulado, tais como as crianças e os escravos. Não se trata de uma alternância nas estruturas do poder, mas de priorizar um poder que é precedido pelo serviço e preterir um poder baseado na dominação.

Quanto ao evangelho de João, ao narrar a crucificação e morte de Jesus, assinala que as mulheres e o discípulo amado lá estavam (BíBLIA DE JERUSALÉM, 2004, Jo 19, 25-27). Schüssler Fiorenza (1992, p. 378-79) considera que um dos significados prováveis dessa passagem "está indicado possivelmente pela afirmação explícita de que a mãe de Jesus tornou-se parte da comunidade joanina depois da morte e ressurreição e Jesus". Chama a atenção o fato de que nem Maria nem João são nomeados. Tanto nesta perícope quanto nas Bodas de Caná (BÍBLIA DE JERUSALÉM, 2004, Jo 2, 4) Jesus se dirige a Maria chamando-a de "mulher", o que, para as exegetas, configura uma caracterização de Maria como discípula e apóstola. Para a mesma autora, há aqui uma proximidade com Marcos (BÍBLIA DE JERUSALÉM, 2004, Mc 3, 31-35). Também nessa passagem é enfatizada a comunidade do discipulado de Jesus como substituta de todos os vínculos da família patriarcal.

Na morte de Jesus, a 'nova família' de discípulos fica constituída, fazendo-os assim irmãos e irmãs. A cena busca, pois, comunicar a mesma mensagem que se dá no prólogo: 'Veio para o que era seu, mas os seus não o receberam. Mas a todos que o receberam deu o poder de se tornarem filhos de Deus: aos que creem em seu nome' (1, 11 -12). O Discípulo Amado representa, pois, os discípulos de Jesus que, tendo deixado tudo, agora recebem uma 'nova comunidade', casa, e irmãos, e irmãs, e mães, e filhos, e terras, e na idade a vir 'vida eterna' (Mc 10, 29-30). A nova comunidade joanina parece ter compreensão semelhante à de Marcos, ou seja, que a 'nova comunidade familiar' vai incluir 'mães', e também irmãos e irmãs, mas não pais - porque o seu pai é somente Deus (SCHÜSSLER FIORENZA, 1992, p. 379).

Segundo a tradição judaica, quando uma mulher ficava viúva sem os filhos que pudessem Ihe dar assistência, deveria ficar sob a tutela do parente mais próximo. Ora, segundo o Evangelho, Jesus tinha outros "irmãos", no sentido de parentes próximos, e estes naturalmente amparariam a Maria. Porém, estas últimas palavras de Jesus proclamadas na cruz dão primazia à família do discipulado, entregando Maria aos cuidados do discípulo. Inversamente, Maria é apontada como a Mãe de João; extensivamente, ela é mãe de quaisquer discípulos que prestem adesão à pessoa de Jesus e à Boa-nova anunciada por Ele. A valorização do discipulado por parte de Jesus liberta as mulheres do moralismo e do legalismo que as desumanizavam, relegando-as uma condição inferior. Jesus procura evitar a ênfase que se dava ao vínculo familiar, vínculo esse tendencioso, na medida em que permitia e legitimava a submissão das mulheres pelos homens.

\section{A ressignificação da nomeação divina como Pai}

Ao mesmo tempo que as teólogas feministas constatam a forte presença da linguagem patriarcal quando se fala do Pai, elas sustentam que, na Bíblia, o uso do termo Pai para designar a relação com Deus também envolve a ruptura com o patriarcado. Ruether destaca que tanto no AT como no NT são invocadas "a soberania e a paternidade divinas para romper os laços da servidão sob reis e pais humanos" (RUETHER, 1993, p. 59). Lembra que, no Antigo Testamento, por exemplo, Abraão é adotado por Deus somente quando rompe radicalmente os laços familiares, ao deixar para trás o túmulo de seus ancestrais. Do mesmo modo, no Êxodo, o relacionamento de Deus com o povo envolve o rompimento da obediência aos suseranos egípcios dominadores.

Essa linguagem do AT é atualizada no ensinamento de Jesus. O movimento de Jesus emprega continuamente o vocábulo Abba para nomear Deus. Essa denominação se refere à relação primária baseada no respeito, no amor, na confiança e na afeição. Abba é um termo utilizado tanto pelo filho em relação ao pai, como de um adulto para com uma pessoa mais velha. Na boca de Jesus, ele significa a ruptura com as relações de dominação-dependência procedentes dos laços de parentesco ou da assimetria entre senhor e escravo.

A despatriarcalização da imagem de Deus pela ressignificação do termo Abba tem sido trabalhada por Sallie McFague (1996) em seu livro Modelos de Deus: teologia para uma era ecológica e nuclear.

Para começar, a autora constata que, ultimamente, as teólogas feministas cristãs se opuseram tenazmente ao caráter hierárquico e androcêntrico da tradição religiosa ocidental, ao mesmo tempo que buscaram a integridade entre todos e o valor igual à condição humana em suas diferentes divisões. Porém, pouca atenção foi concedida à divisão entre o mundo humano e o mundo não humano. Quando muito, se concentraram no estudo sobre deusas relacionadas a terra e aos ciclos da natureza; jamais estenderam sua reflexão para o valor intrínseco do não humano em vista da mudança de consciência. Por sua vez, as teologias da libertação propuseram que a redenção não se limita à salvação de determinados indivíduos para a vida eterna em outro mundo, "mas a[à] vida plena de toda a humanidade nas realidades políticas e sociais deste mundo" (McFAGUE, 1996, p. 23). No entanto, essa concepção de redenção ainda é demasiado antropocêntrica ao não incluir o bem-estar de qualquer espécie 
de vida. A teologia metafórica, pelo contrário, pretende mostrar que o ser mais insignificante também deve ser considerado, que não nos pertencemos a nós mesmos, que no universo tudo está relacionado. No modelo orgânico, não há limites mecanicistas entre o espírito e o corpo, a razão e a paixão, o humano e o não humano. Além disso, esse modelo está baseado em uma perspectiva evolutiva de interdependência entre os seres, segundo a qual se propõe que a única coisa permanente é a mudança, a forma de definir uma entidade é somente pelo conjunto de suas relações.

Em segundo lugar, os deslocamentos que McFague proporciona na nomeação de Deus são particularmente relevantes para a teologia feminista: de Deus Pai, no sentido de patriarca, para o de Deus pai/mãe, na condição de genitores; do Deus juiz, que pune, para Deus-mãe juíza, que distribui a justiça; de um Deus soberano que governa o mundo, ao Deus amigo que convive no mundo; de Deus salvador que redime os pecadores, ao Deus amante que vê o mundo como algo valioso e que depende de nossa cooperação para que seja salvo. Além disso, ela ressignifica o sentido de paternidade divina ao deslocá-la das estruturas de parentesco para a ideia de paternidade universal, no sentido de pai e mãe do mundo.

McFague nomeia e ressignifica o divino utilizando metáforas que levam em conta a sexualidade, o amor e a paixão, sem cair no sexismo. Trata da paternidade sem ser patriarcal; aborda o feminino sem ser feminil; enfatiza a maternidade sem apelar para atitudes culturalmente maternais. Desse modo, ela nomeia e ressignifica Deus pelas perspectivas maduras do amor humano as quais, ao mesmo tempo, constituem respostas razoáveis para o mundo atual, assolado tanto pela crise ecológica quanto pelo pesadelo nuclear. Seria deveras interessante analisar cada um desses deslocamentos operados por McFague. Contudo, considerando as delimitações deste artigo, atemo-nos somente à sua proposta de despatriarcalização de DeusPai pela metáfora de Deus como pai/mãe do mundo, na tentativa de identificar quais são seus desdobramentos para as relações humanas.

A teologia cristã ocidental desconfiou da nomeação de Deus como mãe em razão do medo histórico da sexualidade feminina e seu fascínio. No entanto, se tomarmos a nós mesmas como modelos para falar sobre Deus - e não uma linguagem de gênero neutra -, é porque somos seres sexuais. McFague propõe que: 1) Deus seja imaginado em termos femininos não feminis; 2) que as metáforas femininas devam incluir as maternais, mas não se limitar a elas.

No que diz respeito à primeira proposta, a autora ressalta que:

O problema ao introduzir uma dimensão feminina de Deus é que invariavelmente termina-se identificando como femininas as qualidades que a sociedade chamou de feminis. Então, o lado feminino de Deus é tomado para compreender os aspectos ternos, protetores, passivos e curadores da atividade divina, ao passo que as atividades nas quais Deus cria, redime, estabelece a paz, administra a justiça e assim por diante, são chamadas masculinas (McFAGUE, 1996, p. 141).

São atribuídos à divindade os próprios estereótipos criados socialmente. Em contrapartida, a teologia metafórica afirma que "Deus é ela e ele e nenhum dos dois" (McFAGUE, 1996, p. 142).

No que concerne à segunda proposta, pesquisas atuais mostram que nas religiões "as atividades divinas são atribuídas equivalentemente a agentes masculinos e femininos" (McFAGUE, 1996, p. 143). McFague lembra que, embora se fale de mãe para integrar a Deus como Pai, outras atividades divinas podem ser figuradas na imagem feminina. De outro modo, embora servir de mãe seja uma atividade feminina, não é feminil: pode-se dar à luz e nutrir de modo feminil ou não.

Cumpre agora explicitar o amor de Deus como mãe, relacionado ao termo grego ágape. McFague destaca que, no Ocidente, o ágape quase sempre se referiu ao amor desinteressado, sem desejo, sem necessidades e assim por diante. Sua proposta é que o amor ágape não precisa ser compreendido como um amor desinteressado, se ele for associado ao dom da vida, à criação. Ele não pode ser isolado de outras formas de amor, como eros e filia. Ágape deve ser um amor favorável à vida no sentido de que se interessa por todas as espécies, e não apenas pela humana; além disso, porque ele se interessa pelo sustento da plenitude da vida e não somente pelo seu nascimento.

O modelo pai/mãe tem três características básicas: ele nos leva para mais perto das origens da vida, do sustento da vida e da imparcial plenitude da vida. Quanto à primeira, tratase de um amor que transcende o aspecto biológico e/ou adotivo da paternidade. McFague chega a dizer que todo ser humano tem inclinações paternais, o potencial de passar a vida adiante, de permitir que próximas gerações - e não apenas a humana - possam existir. O ensino, a medicina, a jardinagem e o trabalho social são tantas formas do exercício dessa paternidade. McFague pensa que a tradição cristã ignorou, nos seus rituais, o nosso primeiro nascimento, o nascimento físico; privilegiou, nos seus símbolos, o segundo nascimento, considerado espiritual. Porque associada à sexualidade feminina, prescindiu-se do nascimento concreto. O modelo de Deus como mãe sugere uma criação diferente, como corpo de Deus. 
E é claramente o genitor como mãe o candidato mais forte para uma compreensão da criação enquanto corporificada pelo ser divino, pois são as imagens de gestação, parto e amamentação que criam uma figura imaginativa da criação como profundamente dependente da vida divina e cuidada por ela (McFAGUE, 1996, p. 151).

Quanto à segunda característica, temos a sustentação da vida. A tradição veterotestamentária, assim como os Evangelhos, deu muita importância ao ato de comer. Jesus é visto comendo com pecadores e prostitutas; Ele multiplica os pães e os peixes. Por sua vez, a Igreja apresenta a ceia eucarística como centro de suas celebrações e pré-anúncio do banquete escatológico. Relevante é lembrar que o cristianismo foi reticente com as imagens do nascimento - porque associadas aos processos femininos naturais - mas não à experiência do comer, como símbolo da nutrição espiritual. O problema é que, muitas vezes, no decorrer da história da lgreja, preocupou-se demasiadamente com o alimento espiritual e negligenciou-se a luta em torno do alimento físico.

A terceira característica ensina que o amor pai/mãe conduz à imparcial plenitude da vida. McFague prefere falar de amor agápico inclusivo como modelo de justiça imparcial. $O$ amor divino é inclusivo e opera a despeito dos obstáculos; pode, assim, ser amor de todos, de todas as espécies, independente de quaisquer barreiras. Se como pais tendemos instintivamente a saciar os membros de nossa própria espécie, então só podemos expressar este amor de Deus de modo parcial e distorcido.

Certamente, quando ampliamos o modelo além da sua base física para incluir nossas inclinações paternais para crianças que não são nossos filhos, como também para formas de vida que não são a nossa, emerge uma atitude de imparcialidade, de abrangência, mas apenas como uma tênue imitação do ágape divino (McFAGUE, 1996, p. 154-155).

Convém saber a que tipo de atividade divina corresponde o amor ágape. O modelo de afirmação teológica que nasce do modelo Deus-mãe é a doutrina da criação. Esta doutrina, em função da evolução do conhecimento científico, foi questionada nos últimos trezentos anos. Ela está apoiada em duas ideias fundamentais: que Deus criou o mundo ex nihilo; que criou tudo hierarquicamente, ao subordinar o físico ao espiritual. Estas ideias dão sustentação ao dualismo: a distinção absoluta entre Deus e mundo; a inferioridade da matéria em relação ao espírito, do corpo em relação à mente. Trata-se do modelo artístico da criação, pelo qual Deus forma o mundo, seja intelectualmente pela palavra (criação da mente), seja esteticamente pela arte (criação das mãos). A humanidade é colocada acima da natureza e o espírito sobrevalorizado em relação ao corpo, potencializando assim a distância e a diferença absoluta entre Deus e mundo.

Um quadro imaginativo alternativo emerge do modelo Deus-mãe. Trata-se de pensar a criação não como ato intelectual ou estético, mas como evento físico no sentido de que o universo é formado por Deus e constitui expressão de seu próprio Ser. Aqui, pode-se evocar metaforicamente o parto, pelo qual o universo é criado do seio de Deus. "Não é algo estranho a Deus ou outra coisa que ele, mas nasce do 'seio' de Deus, formado por 'gestação'” (McFAGUE, 1996, p. 157).

Um dos desdobramentos desse modelo é que "o universo e Deus não são totalmente distantes nem totalmente diferentes" (McFAGUE, 1996, p. 157): eles estão próximos e são semelhantes ao modo como mãe e filho têm um senso de afinidade e parentesco. No entanto, há uma diferença. Quando damos à luz, não é a nossos corpos, mas a filhos de nossos corpos. Somos transmissoras da vida. Por sua vez, Deus é criador, fonte da vida. McFague sugere conciliar essa afirmação com a sensibilidade holística evolutiva. Ao imaginar Deus dando à luz seu próprio corpo, ou seja, a vida, isso fornece um modelo de afinidade muito diverso da distância e diferença do modelo artístico.

Outro desdobramento desse modelo é sua subversão do dualismo entre matéria e espírito. O corpo de Deus, que sustenta a vida, não é matéria ou espírito, mas matriz da qual evolui tudo quanto existe. McFague ressalta a dificuldade de imaginar a Deus em termos físicos, posto que sua dimensão espiritual reina quase absolutamente. No entanto, se pensarmos o universo como o outro de Deus, se o corpo de Deus é todo complexo orgânico de que fazemos parte (semelhante a Deus, mas não idêntico a ele), então Deus pode ser físico como também espiritual. Ele, portanto, precisa do mundo e o deseja não simplesmente como um dependente inferior (a matéria subordinada ao espírito), mas, como prole, ser amado e companheiro.

Deus como mãe-criador também é inseparável à sua ressignificação como Juiz. Aqui não se trata da imagem de um juiz que condena, mas que está empenhado na contínua defesa dos filhos para que eles existam, possam alimentar-se e crescer. "A metáfora de Deus como mãe que estamos considerando é construída não sobre estereótipos de ternura, suavidade, piedade e sentimentalidade maternas, mas sobre a experiência feminina de gestação, parto e lactação" (MCFAGUE, 1996, p. 161). 
Deus encoleriza-se porque seus filhos e filhas e todos os demais seres, que nasceram do seu ser e lhe pertencem, não têm alimento e outras coisas necessárias para crescer e prosperar por causa do pecado introduzido no mundo, como o pecado da injustiça.

Deus-mãe como criador/a é necessariamente juiz/a, no nível mais fundamental de condenar como pecado primário (embora não único) a injusta distribuição dos recursos essencialmente necessários para a continuação da vida em suas muitas formas. Neste modo de ver, então, o pecado não é 'contra Deus', o orgulho ou rebeldia de um inferior contra um superior, mas 'contra o corpo', a recusa de ser parte de um todo ecológico, cuja continuada existência e sucesso dependem de um reconhecimento da interdependência e inter-relação de todas as espécies. Portanto, o Deus-mãe como criador/a está também envolvido em assuntos 'econômicos', a administração do governo do universo, para assegurar a justa distribuição dos bens (McFAGUE, 1996, p. 161-162). ${ }^{3}$

McFague vê no modelo Deus-mãe a divindade envolvida com a natureza (dar a vida) e com o governo da história (realizar a plenitude da vida). Na tradição hebraica, esta unidade entre natureza e história, atividade de procriação e justiça, encontra-se na Sabedoria ou Sofia. "Sofia não é Deus em forma feminina, mas [...] a presença imanente de Deus em todas as coisas." Suas atividades se estendem da ordem natural à preocupação com os pobres, sofredores e excluídos. "Mas o interessante é que muitas das características atribuídas tanto a Jesus de Nazaré como ao Logos são qualidades antes atribuídas à Sofia - desde comer e beber com marginais até servir de agente de Deus na criação, redenção e preservação" (McFAGUE, 1996, p. 163).

Convém salientar qual a mensagem desta espécie de amor sobre a existência de nosso mundo. Trata-se de investigar a ética de Deus como mãe, assentada no princípio da justiça. McFague evoca o mandamento "amar a Deus e ao próximo/a como a si mesmo/a" e ressalta o desconforto desse critério do amor próprio na tradição cristá, principalmente entre os protestantes, os quais acreditam que o eu se encontra corrompido pelo pecado original. ${ }^{4}$ No entanto, no contexto da doutrina do mundo criado como corpo de nosso Deus-mãe, o mandamento significa "desejar para os/as outros/as a existência, o direito de nascer, o direito à nutrição, à plenitude, que cada um deseja para si mesmo/mesma" (McFAGUE, 1996, p. 166). Na imagem de Deus-mãe, a justiça não é entendida como condenação e libertação dos culpados/ as, mas como justa ordenação do governo do cosmo, de modo a beneficiar a todos/as. Deus mãe-juiz/a é aquele/a que estabelece a justiça, não a que distribui sentenças.

Decisivo na postura de McFague é não se contentar com a indicação de estilos de vida para cristãos/cristãs individuais, mas apontar uma imagem heurística, uma estrutura para interpretar a fé cristã na era ecológica e nuclear. Lembra que, em algumas teologias da libertação - mas não especifica quais são elas -, o evangelho da fé cristã centraliza-se no estabelecimento de uma ordem sociopolítica-econômica justa para o ser humano, embora ela seja insuficiente.

Nessas teologias, a busca pelo direito à existência e pelos meios necessários para viver é reivindicada somente para os seres humanos, com menor atenção para outros níveis de seres. De modo similar, não há grande preocupação em relação às gerações ainda não nascidas da nossa e de outras espécies. A vantagem teórica da articulação entre o empobrecimento econômico e a ameaça do desastre nuclear consiste em realçar que a opressão e a dominação não se restringem ao presente e à espécie humana, mas também se estendem ao futuro e à impossibilidade da vida de quaisquer espécies. Quer dizer, em muitas teologias da libertação, o problema da justiça esteve ligado ao problema ecológico e nuclear, mas somente como um problema humano, histórico e econômico.

McFague entende que a história é inseparável da natureza; e a justiça, do cuidado com o mundo. Além de libertar a humanidade das estruturas opressoras, não se pode deixar de lado o mundo que fornece todos os bens a seres distribuídos justamente. Deveríamos nos tornar pais e mães para nosso mundo, assumir uma espécie de paternidade/maternidade universal. Tratase da vontade de permitir que outros venham a existir, "a vontade não de salvar a nós mesmos, mas de trazer outros à existência" (McFAGUE, 1996, p. 166). A paternidade/maternidade universal deve, em primeiro lugar, estender-se para além de nossa própria espécie, de modo a tornar-nos jardineiras e zeladoras de nosso Éden. Em segundo lugar, ela deve ser compreendida para além do nascimento, na direção do bem-estar completo de nossos sucessores. Isso ocorre das mais variadas maneiras, desde as pessoas comprometidas com um trabalho remunerado ou não, até aquelas empenhadas em sustentar as gerações presente e futura. Mais que a proposta de um novo modelo de sociedade, procura-se a conversão da consciência.

\footnotetext{
${ }^{3}$ A introdução de uma linguagem de gênero nesta citação é de nossa responsabilidade, pois, na tradução da obra à língua portuguesa, ainda remanesce a linguagem unicamente masculina.

${ }^{4}$ Em razão dessa corrupção do eu é que Lutero postula que o "ser humano é ao mesmo tempo santo e pecador" (homo simuls sanctus et peccator): o eu é sempre pecador/a, razão pela qual o ser humano é santificado somente pela graça e não em função das suas obras. Essa visão antropológica e teológica de Lutero foi anatematizada no cânon 11 , do Tratado sobre a Justificação, no Concílio de Trento.
} 
Propor novos modelos de Deus - ainda que antigos, posto que inspirados na Bíblia, particularmente no Quarto Evangelho - envolve, portanto, deslocar quaisquer imagens que legitimaram estruturas de dominação específicas, e, em seguida, imaginar como um Deus pai/ mãe poderia resultar na ressignificação de relações humanas mais integradoras, recíprocas e autênticas. Entretanto, é mister lembrar a advertência mais incisiva feita por McFague a respeito de sua delimitação teórica:

Não fazemos pronunciamentos, mas experiência; não lidando com todos os modelos possíveis, mas com apenas um; não sugerindo que o nosso modelo compreende uma completa doutrina de Deus, mas apenas certos aspectos; não supondo que o modelo valha para qualquer época, mas apenas para a nossa. O caráter heurístico, limitado e oportuno da teologia metafórica deve ser sempre conservado ante os olhos: a audácia imaginativa não é o mesmo que pronunciamento dogmático e são diferentes os critérios para julgar cada um. Se pudermos fazer a defesa do nosso modelo, ele será quando muito plausível, esclarecedor e oportuno: nunca será o único e a única verdade (McFAGUE, 1996, p. 134).

\section{Consideraçōes finais}

Pelo estudo feito até aqui, evidencia-se a relevância da renomeação divina ou dos novos significados que podem ser atribuídos às nomeações já existentes. A relação afetiva e amorosa que envolve chamar a Deus de Pai (ou Mãe) tem um sentido diferente da imagem de Pai associada ao governo da esposa e dos filhos, dos quais são exigidas somente resignação e obediência irrestritas.

A despeito da riqueza incomensurável da renomeação de Deus e das propostas de ressignificações de suas nomeações já existentes observadas nesta pesquisa, reconhecemos a precariedade da linguagem humana para descrever o mistério de Deus. Nesse aspecto, tem sido importante a constatação de que JHWH, o Deus da Revelação de Israel, se apresentou com muita sobriedade: "Aquele que é, Aquele que está conosco, Aquele que faz ser, origem e causa da existência, o Ser que se desdobra" (Catharina HALKES, 1980, p. 115). Deus é o inefável, o inominável que encontramos no episódio da sarça ardente. "Eu sou o que Sou" denota que o 'Ser' de Deus não muda em função das contingências culturais; que nenhuma linguagem humana pode esgotar a essência de Deus; que sua atribuição masculina e seus desdobramentos patriarcais são somente projeções culturais sexistas que despotencializam a riqueza incomensurável de outras imagens mais integradoras de Deus.

Essa escolha pela teologia apofática ${ }^{5}$ a respeito da nomeação do divino não obsta que continuemos a nomear Deus de Pai, Senhor e Rei, Onipotente e Perfeito. A objeção refere-se ao uso de tais denominações para justificar poderes e estruturas humanas excludentes e patriarcais. Conforme realça Elisabeth Johnson (2010), "apesar da sabedoria apofática de que Deus habita numa luz inacessível, que nenhum homem viu nem pode ver (BíBLIA DE JERUSALÉM, 2004, 1 Tim 6,16 ), a maneira padrão de falar na igreja molda Deus quase que exclusivamente pelo ser humano masculino" (JOHNSON, 2010, p. 41).

Foi justamente para denunciar essas estruturas e essa maneira padrão de falar de Deus, que buscamos, neste artigo, propor relações humanas mais integradoras e inclusivas de modo heurístico, metafórico, imaginativo, que fossem capazes de ressignificar os nomes de Deus.

Halkes (1980, p. 115) considera que o problema de Deus é uma das contribuições mais importantes oferecidas pela teologia feminista, quando ela almeja ser processual e integradora. A teologia feminista, ao ressaltar novas hermenêuticas da escritura e um novo pensamento sistemático sobre o divino, define sua opção preferencial pela afirmação da dignidade das mulheres e crianças como parte de uma perspectiva multidimensional da criação de um mundo mais justo (Mary HUNT, 2009). Desta forma, a nomeação divina feita pela teologia feminista "reflete esse objetivo ao atentarmos para o racismo, colonialismo, discriminação de pessoas portadoras de deficiência, heterossexismo e sexismo" (HUNT, 2009), e outras situações humanas de vulnerabilidade e exclusão.

No nível dos conceitos, essa teologia procura se opor a um Deus onisciente e onipotente, unicamente transcendente com traços tipicamente poderosos. Em contrapartida, ela enfatiza a imanência de Deus no sentido de que "nosso ser é uma participação do Ser de Deus numa reciprocidade oferecida e recebida" (HALKES, 1980, p. 116). Contudo, enfatizar a imanência de Deus não significa negar sua transcendência. Pretende-se somente desapegar-se de uma transcendência interpretada como separação de nosso mundo ao mesmo tempo que se sublinha sua imanência no sentido de um Deus conosco. Sem se identificar com suas criaturas, Deus nos oferece seu ventre para que, na sua proteção e aconchego, possamos estabelecer

\footnotetext{
${ }^{5}$ A teologia apofática (ou teologia negativa) entende que, ao buscar uma compreensão de Deus/a, não se atribui a ele/ela predicados ou, até mesmo, a categoria ser. Ele/Ela é o/a nome sem nome. Há, portanto, na pessoa divina, a superação de todos os atributos. Um grande expoente dessa teologia é o místico Pseudo-Dionísio, do século V, que irá influenciar o pensamento teológico medieval.
} 
nossas escolhas, construir alteridades sustentadas em relações recíprocas, atuar em defesa da vida e nos solidarizarmos com aqueles/as que mais sofrem.

A "imanência" divina indissociável de sua absoluta transcendência também pode ser contemplada pelo viés da crise ambiental e da ameaça nuclear. Nesse sentido, McFague procura redimensionar a relação entre Deus e Mundo pela teologia heurística e metafórica. Ela evoca modelos de Deus imaginativos que propiciem uma relação integradora com o mundo criado em geral, e com os seres humanos, em particular. Aponta a insuficiência do modelo monárquico ufanista pelo qual Deus é identificado ao imaginário da soberania política do Rei e Senhor do universo. Esta linguagem acerca do divino torna Deus distante dos seres humanos, dos quais são solicitadas obediência e benevolência.

A teologia metafórica de McFague parte da realidade da ameaça nuclear, da percepção evolutiva da interdependência entre todos os seres e do movimento feminista da libertação para imaginar Deus pai/mãe no mundo e o mundo como corpo de Deus. Ainda que a perspectiva de McFague não seja diretamente feminista, sua proposta desliza em direção de uma heurística de modelos de Deus integradores desde os quais o antropocentrismo perde força, ao mesmo tempo que é reforçada a interdependência com os demais seres criados.

\section{Referências}

BíBLIA DE JERUSALÉM. Vários tradutores. São Paulo: Sociedade Bíblica Católica Internacional e Paulus, 2004.

BINGEMER, Maria Clara Lucchetti. "Masculinidade e feminilidade: Duas faces do mistério de Jesus Cristo". Concilium: Revista Internacional de Teologia, v. 3, n. 326, p. 45-56, 2008.

DALY, Mary. Beyond God the Father, Toward a Philosophy of Women's Liberation. Boston: Beacon Press, 1975.

GEBARA, Ivone. "500 Anos e o Discurso sobre o mal feminino". Impulso, Piracicaba, n. 27, p. 272$284,2000$.

GIBELLINI, Rosino. "A outra voz da teologia: esboços e perspectivas de teologia feminista". In: LUNEN-CHENU, Marie-Thérèse Van; GIBELLINI, Rosino. Mulher e Teologia. São Paulo: Loyola, 1992. p. 71-133.

GUSDORF, Georges. La parole. Paris: PUF, 1990.

HALKES, Catharina. "Teologia Feminista - Balanço provisório". Concilium: Revista Internacional de Teologia, v. 4, n. 154, p. 109-122, 1980.

HENRIQUES, Fernanda. "Dizer Deus - Outras Metáforas". In: SILVA, Manuela (Org.). Dizer Deus: Imagens e linguagens. Lisboa: Gótica, 2003. Disponível em http://home.uevora.pt/ fhenriques/ textos-filegenero/dizerdeus.pdf. Acesso em 25/11/2020.

HUNT, Mary. "Os nomes de Deus e o empoderamento feminino". Entrevista de Mary Hunt à Márcia Junges. Revista do Instituto Humanitas Unisinos [online], São Leopoldo, n. 308, 14/09/2009. Disponível em http://www.ihuonline.unisinos.br/artigo/2818-mary-hunt-2. Acesso em 12/12/2019.

JEREMIAS, Joachim. Jerusalém no tempo de Jesus. São Paulo: Paulinas, 1983.

LAGARDE Y DE LOS RÍOS, Marcela. El feminismo en mi vida: hitos, claves y utopías, 2012. Disponível em http://www.mujeresenred.net/IMG/pdf/ElFeminismoenmiVida.pdf. Acesso em 03/12/2020.

JOHNSON, Elisabeth. "Female Symbols for God: The Apophatic Tradition and Social Justice". International Journal of Orthodox Theology, v. 1, n. 2, p. 40-57, 2010.

MACKENZIE, John L. Dicionário Bíblico. 29. ed. São Paulo: Paulinas, 1983.

MALONEY, Linda M. "A questão da diferença feminina na filosofia clássica e no cristianismo primitivo". Concilium: Revista Internacional de Teologia, v. 6, n. 238, p. 52-61, 1991.

McFAGUE, Sallie. Modelos de Deus: teologia para uma era ecológica e nuclear. Tradução de José Raimundo Vigidal. São Paulo: Paulus, 1996.

RICOEUR, Paul. Le conflit des interprétations: essais d'herméneutique. Paris: Seuil, 1969.

RUETHER, Rosemary Radford. Sexismo e Religião: Rumo a uma Teologia Feminista. São Leopoldo: Sinodal, 1993. 
SCHÜSSLER FIORENZA, Elisabeth. As origens cristãs a partir da mulher. Uma nova hermenêutica. São Paulo: Paulinas, 1992.

TAMEZ, Elsa. "Hermenéutica feminista latinoamericana, una mirada retrospectiva". In: TEPEDINO, Ana Maria; AQUINO, Maria Pilar (Orgs.). Entre la indignación y la Esperanza. Teología Feminista Latinoamericana. Bogotá: Indo-American Press Service Ltda., 1998. p. 41-60.

TAVARES, Sinivaldo. Teologia da criação. Outro olhar - novas relações. Petrópolis: Vozes, 2010.

TEPEDINO, Ana Maria. Gênero e Religião. Texto em folhas avulsas. s.d., p. 1-9.

TOLDY, Teresa Martinho. Deus e a palavra de Deus na teologia feminista. Lisboa: Paulinas, 1998.

TRIBLE, Phyllis. "Depatriarchalizing in Biblical Interpretation". Journal of The American Academy of Religion, v. 1, n. 41, p. 30-48, 1973.

Jaci de Fátima Souza Candiotto (i.candiotto@pucpr) é professora do Mestrado em Direitos Humanos e Políticas Públicas (PUCPR) e do curso de Teologia da PUCPR. Possui Pósdoutorado no Institut Catholique de Paris, França (2014-2015), Doutorado em Teologia (2012) e Mestrado em Teologia (2008) pela Pontifícia Universidade Católica do Rio de Janeiro, Mestrado em Educação pela Pontifícia Universidade Católica do Paraná (2002).

\section{COMO CITAR ESTE ARTIGO DE ACORDO COM AS NORMAS DA REVISTA}

CANDIOTTO, Jaci de Fátima Souza. "A despatriarcalização de Deus na teologia feminista". Revista Estudos Feministas, Florianópolis, v. 29, n. 3, e73607, 2021.

\section{CONTRIBUIÇĀO DE AUTORIA}

Não se aplica.

\section{FINANCIAMENTO}

O presente trabalho foi realizado com apoio financeiro do Conselho Nacional de Pesquisa (CNPq), processo 406577/2016-1.

\section{CONSENTIMENTO DE USO DE IMAGEM}

Não se aplica.

\section{APROVAÇĀO DE COMITÊ DE ÉTICA EM PESQUISA}

Não se aplica.

\section{CONFLITO DE INTERESSES}

Não se aplica.

\section{LICENÇA DE USO}

Este artigo está licenciado sob a Licença Creative Commons CC-BY 4.0 International. Com essa licença você pode compartilhar, adaptar, criar para qualquer fim, desde que atribua a autoria da obra.

\section{HISTÓRICO}

Recebido em 06/05/2020

Reapresentado em 04/12/2020

Aprovado em 10/02/2021 